\title{
POST-FIRE RECOVERY OF TERRESTRIAL VERTEBRATES IN THE KERZHENSKY STATE NATURE BIOSPHERE RESERVE (CENTRAL VOLGA REGION, RUSSIA)
}

\author{
Andrei A. Lebedinskii ${ }^{1}$, Olga S. Noskova ${ }^{1}$, Alexander I. Dmitriev² \\ ${ }^{1}$ Lobachevsky State University of Nizhni Novgorod, Russia \\ e-mail:leb-nn@yandex.ru,noskova.o.s@gmail.com \\ ${ }^{2}$ Nizhny Novgorod State Pedagogical University, Russia \\ e-mail:dmitriev-50@mail.ru
}

Received: 23.10.2018. Revised: 29.05.2019. Accepted: 27.07.2019.

\begin{abstract}
In the summer of 2010, about half of the Kerzhensky State Nature Biosphere Reserve territory (total area is 467.9 $\mathrm{km}^{2}$ ) suffered from a wildfire. During the seven following years, monitoring of the terrestrial vertebrate populations was conducted there. In total, six amphibian species, six reptile species, 142 bird species, and 20 small mammal species were registered. The particular wildfire impact on different vertebrate species was dissimilar. In the first year after the wildfire impact, bird populations in the habitats affected by different wildfire types were similar according to the Sorensen-Chekanovsky's index. This similarity increased over time. The species richness changed in different directions. At first study years, the abundance of the nesting bird populations increased both in burnt and unburnt sites, while later this parameter decreased a bit and stabilised. The bird populations of the unburnt habitats differ by lower indicators for the last five years. We distinguished the species (e.g. Sylvia communis) recognised as indicators of damaging by fire. These are birds which became abundant in the burnt forest, but were very rarely dominant and less abundant in unburnt forest. Fringilla coelebs was dominant in all habitats studied. For the small mammal communities, the wildfire influence affected a decrease (by 2-3 times) in the abundance and biodiversity indexes, and a change of dominants (from Clethrionomys glareolus to Apodemus flavicollis). ANOVA showed that the fires with a high degree of reliability $(0.445 ; \mathrm{p}$-level $<1)$ had a higher impact on the small mammal communities. In amphibians and reptiles, the wildfire caused only a decrease in abundance followed by subsequent recovery without changes in community composition. The most intense postfire changes in terrestrial vertebrate (Tetrapoda) populations were observed within the first five post-fire years. The amphibian and the reptile populations recovered after three post-fire years, while the recovery of bird and small mammal communities noted $4-5$ years after the fire.
\end{abstract}

Key words: amphibian, bird, crown fire, surface fire, reptile, route, small mammal

\section{Introduction}

Wildfires arise from both natural (e.g. dry thunderstorms, self-ignition on peat bogs) and anthropogenic causes. In this regard, they represent a phenomenon permanently accompanying wild nature. At the same time, the wildfires have became more frequent with the humanity advent (Bowman et al., 2009; Pausas \& Keeley, 2009), despite some human actions being aimed at fire prevention and post-fire restoration. In this regard, Protected Areas represent important sites to study the natural processes of postfire succession, further recovery of ecosystems and their components destroyed by wildfire.

For a long time, an interest to study the postfire recovery processes in various natural ecosystems has existed. Middendorf (1869) noted an increase in bird diversity at the burnt sites in the East Siberian taiga, explaining it by an increase in the biotopical heterogeneity in the fire-damaged areas. Several authors (Sannikov, 1982; Furyaev, 1996; Granström, 2001; Bond \& Keeley, 2005) studied patterns of the post-fire recovery and the biogeocenose formation, including plant communities. Perera \& Buse (2014) concluded that wildfire is an integral part of the long-term functioning of forest biomes. Similar conclusions were also made on the basis of studies in savannas (Lamotte, 1975).

Concerning the wildfire effects on specific animal groups, it should be noted that most studies have been devoted to the invertebrates, primarily insects (e.g. Lussenhop, 1976; Holliday, 1984, 1992; Wikars, 1997; Gongalsky, 2014). There are fewer publications aimed to study vertebrates. Most of them were devoted to birds (Ibragimov \& Konkin, 1983; Ushakov et al., 1991; Herrando et al., 2005; Kuleshova, 2009; Zozaya et al., 2010; Nikolaev, 2015; Shmeleva, 2017). There are known numerous fire-related studies devoted 
to amphibians, reptiles and mammals worldwide (e.g. Fisher \& Wilkinson, 2005; Zwolak, 2009; Hossack et al., 2013). However, there is still a lack of data on this topic in European Russia. Buyvolov et al. (2012) is a rare example, reported on the recovery of the community structure and abundance of amphibians and reptiles in the steppe ecosystems. The authors showed that both amphibians and reptiles suffered from wildfire which happened 2-3 years before the study. They demonstrated that the small mammal recovery was faster (within one year after the wildfire).

Excessive wildfires affected the Nizhny Novgorod region in the summer of 2010. Some Protected Areas have also suffered from wildfire, including the Kerzhensky State Nature Biosphere Reserve (hereafter - Kerzhensky Nature Reserve). About half of the Protected Area (about $210 \mathrm{~km}^{2}$ ) got burnt (Fig. 1). During the 2011-2017 field seasons, we carried out a study on the wildfire influence and its consequences on the species richness, spatial distribution, relative abundance, and post-fire recovery dynamics of the Tetrapoda populations in the Kerzhensky Nature Reserve. We collected data on amphibians, reptiles, birds, and small mammals.

Previously, we published partially the results of studies devoted to some groups of Tetrapoda animals (Lebedinskii \& Pestov, 2014, 2016, 2017; Noskova et al., 2014, 2017, 2018; Dmitriev et al., 2016). However, no analysis of data on different Terapoda groups has been performed previously. This study was aimed to perform a comparative analysis of amphibians, reptiles, birds and small mammals observed after the 2010 wildfire in the Kerzhensky Nature Reserve.

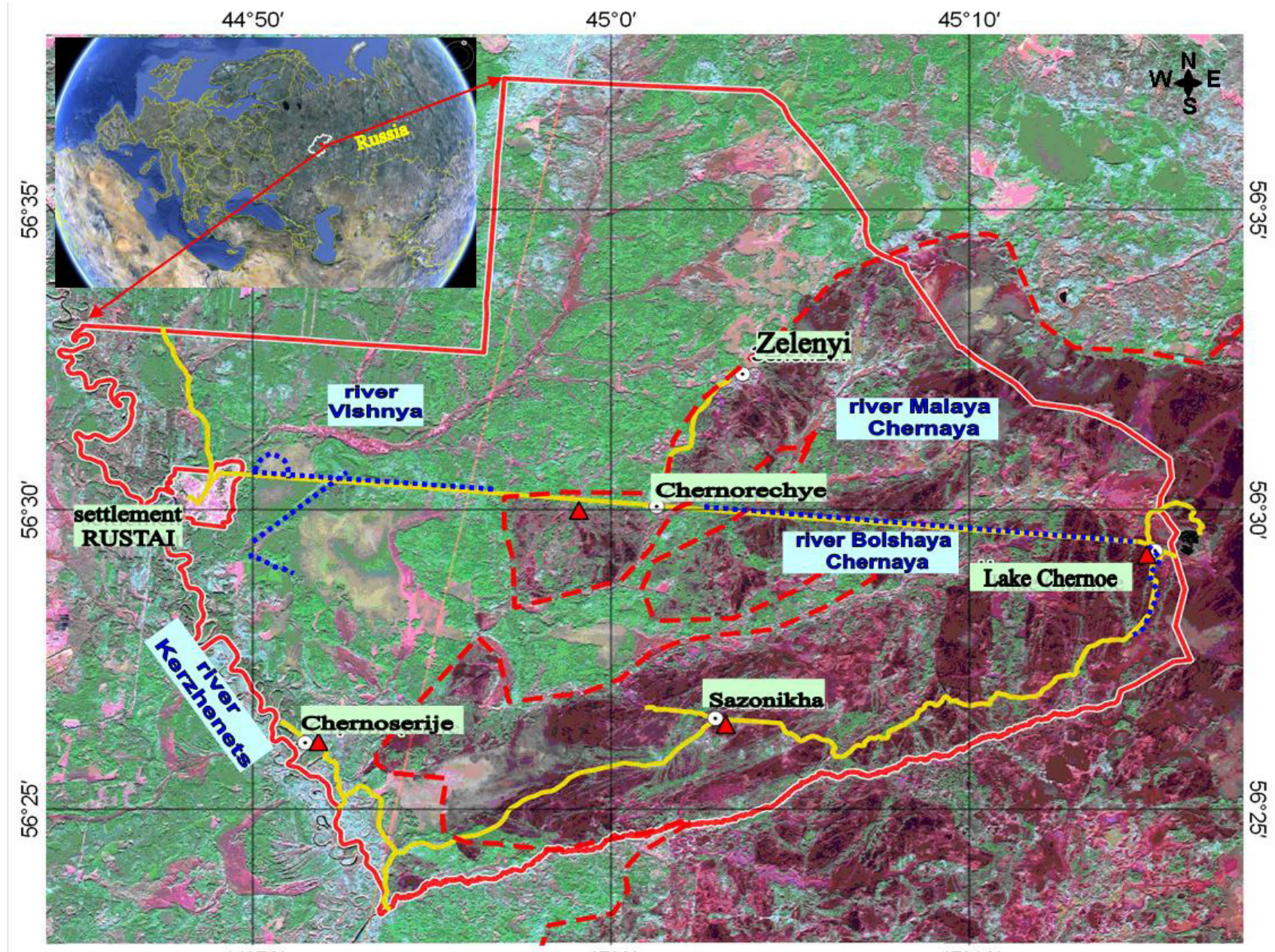

$44^{\circ} 50^{\prime}$

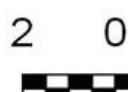

Notes: $45^{\circ} 0^{\prime}$

$12 \mathrm{~km}$ $45^{\circ} 10^{\prime}$

Scale 1:400 000

\footnotetext{
$\square$ - Protected Area borders - routes of the amphibian and reptile counting

$\Delta \quad$ - points of the small mammal collecting
}

\section{(3) - Nizhny Novgorod Region borders}

Fig. 1. The location of the Kerzhensky State Nature Biosphere Reserve, and the border of the wildfire in 2010 within its area. 


\section{Material and Methods}

The Kerzhensky Nature Reserve (total area $-467.9 \mathrm{~km}^{2}$ ) is located $50 \mathrm{~km}$ northeast of Nizhniy Novgorod on the left bank of the River Kerzhenets, a tributary of the River Volga. The Protected Area is situated at the north of the coniferous-broad-leaved forest biome. The Kerzhensky Nature Reserve is a part of wetlands included in the UNESCO International Biosphere Reserve «Nizhegorodskoye Zavolzhye». In the Kerzhensky Nature Reserve, there are large areas of bogs, and young-aged and middle-aged pine (Pinus sylvestris L.) forests (Bakka \& Kiseleva, 2009). During the spring-summer period, the Kerzhensky Nature Reserve regularly suffers from wildfires. We used the schematic map of the Kerzhensky Nature Reserve location (Google Earth), provided by Sergey V. Bakka, and the schematic map of the 2010 wildfires observed in this area (SPOT-5 №sp 118235101019 , 19.10.2010), provided by the scientific department of the Kerzhensky Nature Reserve (Fig. 1).

In the post-fire period (2011-2017), field studies were carried out from spring to autumn. We collected data on amphibians and reptiles in 2012 and 2013. Data on birds were obtained annually in the summers of 2011-2017. In 20112015, studies of small mammals were carried out. Amphibians and reptiles were counted on the routes located on the forest roads according to Novikov (1949). These routes covered all main biotopes in the Kerzhensky Nature Reserve. The accumulated length of walked routes for counting of amphibians and reptiles was $267 \mathrm{~km}$ (137 $\mathrm{km}$ in 2012, and $130 \mathrm{~km}$ in 2013). Birds were counted by a route method without limiting the count strip according to Ravkin (1967). The total accumulated length of the walked routes for bird counting was $2155 \mathrm{~km}$. Of these, $1225 \mathrm{~km}$ were walked during the nesting period, and $930 \mathrm{~km}$ during the post-nesting period. The routes were permanent. And the counting was repeated seven times each summer. To study the small mammals, we used the live animal traps (Karaseva \& Telitsyna, 1998) located at four different sites. Of them, two sites were in burnt forests, and two ones were in unburnt habitats (Fig. 1). Each site included several points of collecting small mammals (37 in total). At each trapping point, live animal traps were arranged in a $500 \mathrm{~m}$-long line with 100 traps in each. At each point, the collecting was carried out once. Points were located along several kilometers from each other, to ex- clude the probability of repeated catching of an animal. In 2011-2015, the total trapping effort equalled 1889 trap-days in which 1043 small mammals were caught.

The selection of the study sites was based on the specifics of the biotopical preferences of animal groups. We also aimed to cover a wider area affected by the wildfires. We determined the following two wildfire types. The surface wildfire does not destroy the forest stand and only partially damages the shrub layer. The crown wildfire usually leads to almost complete destroying forest layers and the forest litter. The habitats of amphibians and reptiles included also sites damaged by surface wildfire, where firefighters conducted fire suppression. In addition, we included the areas non-suffering of the 2010 wildfires aiming to allow comparing the changes between burnt and unburnt areas. The birds were studied during the morning counting. The studies of amphibians and reptiles were conducted during both day- and night-time using a handheld electric torch.

To map locations of animals (except birds) we used a GPS navigator. The data processing was carried out using ArcView GIS 3.2a software. All bird observation data were loaded into the database of the Zoomonitoring laboratory in the Institute of the Systematics and Ecology of Animals of RAS. The staff of this laboratory executed the processing of obtained data. We have considered abundance (density), biomass and other indicators applied in Noskova et al. (2014, 2017, 2018). The biomass calculation was given according to Dementiev \& Gladkov (19511954). To perform the mathematical data processing, we calculated the following parameters: Sorensen-Chekanovsky index, Shannon index, Pielou index, Simpson-Margalef index, Fischer's criterion (Fischer's exact test), ANOVA according to Simpson (1949), Margalef (1958), Pielou (1966), Odum (1986). For statistical processing, we used the Microsoft Excel software. The distribution in selections corresponded to normal one. We estimated the 2010 wildfire influence on the basis of the small mammal abundance using ANOVA. To apply ANOVA, we distributed 37 registration points of small mammals along the gradation of different wildfire impacts without components of this factor (e.g. crown wildfire or surface wildfire), because it often cannot be defined or it can be determined only conditionally (Dmitriev et al., 2016). 


\section{Results and Discussion}

\section{Amphibians and reptiles}

During the study period, we found six amphibian species and six reptile species in the Kerzhensky Nature Reserve. In the burnt sites, the species composition of amphibians and reptiles varied depending on the wildfire type. Combined data on the species composition of the herpetofauna in the study area in 2012 and 2013, and in the whole Protected Area before 2010 (Mannapova et al., 1999; Mannapova \& Pestov, 2002) are presented in Table 1.

In the Kerzhensky Nature Reserve, biotopical preferences of the amphibian and reptile species were quite typical in agreement with Puzanov et al. (2005), who studied this area earlier. However, we noted a visible tendency of the most species to be confined to the sites with detectable traces of human activity (e.g. some ruins of former settlements, ponds, roads) (Lebedinskii \& Pestov, 2014). On the fire-damaged sites, the number of registered amphibian and reptile species were slightly higher in 2012 than in 2013. This year, one new species (Rana temporaria Linnaeus, 1758) was registered, although Lissotriton vulgaris Linnaeus, 1758, Pelophylax k1. esculentus (Linnaeus, 1758), Anguis fragilis Linnaeus, 1758, and Coronella austriaca Laurenti, 1768 could not be found. Lissotriton vulgaris, Rana temporaria, Pelophylax kl. esculentus, Coronella austriaca belong to the rare or singular species. At the same time, Pelophylax lessonae (Camerano, 1882), Rana arvalis Nilsson, 1842, Natrix natrix (Linnaeus, 1758), and Lacerta agilis Linnaeus, 1758 were the most prevailing (Lebedinskii \& Pestov, 2014). Thus, the herpetofauna structure could generally be considered as stable. It was similar to the fauna of amphibians and reptiles on the control sites, and was not significantly affected by the surface wildfire and deliberate burning.

In many cases, the origin of such stability is explained by the close proximity of forests unaffected by the 2010 wildfire (Fig. 1). These intact areas became the dispersal source of animals into the burnt sites after 2010 wildfire. We suggest that in these areas, the existence of a large number of water bodies and marshy biotopes played a significant role. Therefore, these habitats served as survival depots during the surface wildfires. The conditions of the surface wildfire gave a chance to survive for amphibians and reptiles in the water bodies and overmoistened sites. Additionally, the presence of mammal burrows, cavities under roots, old tree hollows, etc. can increase the surviving possibility. These commonly served as customary shelters and not only under conditions of wildfire influence. Moreover, we recorded the appearance of new small water bodies in result of the tree fallout on the bogs after peat burning. Amphibians (primarily, Rana arvalis) subsequently used these habitats for reproduction purposes.

Table 1. The amphibian and reptile species observed in the Kerzhensky State Nature Biosphere Reserve before and after the 2010 wildfire

\begin{tabular}{|c|c|c|c|c|c|}
\hline \multirow{3}{*}{ Species } & \multirow{3}{*}{$\begin{array}{l}\text { Before } \\
2010^{*}\end{array}$} & \multicolumn{4}{|c|}{ The 2010 wildfire types } \\
\hline & & \multicolumn{2}{|c|}{$\begin{array}{l}\text { Surface wildfire; annealing } \\
\text { (cordon Chernorechye) }\end{array}$} & \multicolumn{2}{|c|}{$\begin{array}{c}\text { Crown wildfire } \\
\text { (cordon Sazonikha) }\end{array}$} \\
\hline & & 2012 & 2013 & 2012 & 2013 \\
\hline Lissotriton vulgaris Linnaeus, 1758 & + & + & - & - & - \\
\hline Triturus cristatus Laurenti, 1768 & + & - & - & - & - \\
\hline Pelobates fuscus (Laurenti, 1768) & + & - & - & - & - \\
\hline Bufo bufo Linnaeus, 1758 & + & + & + & - & - \\
\hline Rana arvalis Nilsson, 1842 & + & + & + & - & + \\
\hline Rana temporaria Linnaeus, 1758 & + & - & + & - & - \\
\hline Pelophylax lessonae (Camerano, 1882) & + & + & + & - & + \\
\hline Pelophylax kl. esculentus (Linnaeus, 1758) & - & + & - & - & - \\
\hline Anguis fragilis Linnaeus, 1758 & + & + & - & - & - \\
\hline Lacerta agilis Linnaeus, 1758 & + & + & + & + & + \\
\hline Zootoca vivipara (Lichtenstein, 1823) & + & + & + & - & - \\
\hline Natrix natrix (Linnaeus, 1758) & + & + & + & - & + \\
\hline Coronella austriaca Laurenti, 1768 & + & + & - & + & + \\
\hline Vipera berus (Linnaeus, 1758) & + & + & + & - & - \\
\hline Total species number & 13 & 11 & 8 & 2 & 5 \\
\hline
\end{tabular}

Note: *Data are presented for the whole area of the Kerzhensky Nature Reserve according to Mannapova et al. (1999), Mannapova \& Pestov (2002). 
We observed a very different picture on the sites affected by crown fires. After two post-fire years (i.e. in 2012) on these sites, no amphibian species were found, and the records of reptiles ( $L a$ certa agilis, Coronella austriaca) were singular (Table 1). However, in 2013, we found an almost complete recovery of the abundance of Pelophylax lessonae and Rana arvalis typical to these areas. Natrix natrix re-appeared there. The abundance of Lacerta agilis increased. The abundance of Lacerta agilis recovered up to a level comparable to that on unburnt sites (Lebedinskii \& Pestov, 2014, 2016). It was caused most likely due to reproduction of individuals survived by hiding in some natural shelters after the 2010 wildfire influence (Buyvolov et al., 2012).

During the study years, the records of Coronella austriaca were singular. This correlated with data showing its low abundance at the northern border of its natural range (Puzanov et al., 2005). Natrix natrix was not found in 2012. In 2013, its abundance was still low. Therefore, no significant differences were found between the two years. On the other hand, the important role in this case is played by the complete «burning out» of the small water bodies during the 2010 crown wildfire (Lebedinskii \& Pestov, 2014), and the subsequent slow post-fire recovery of suitable biotopes.

Sandy soils under uneven-age pine forests, prevailed in the study area, contributed to a low amphibian species diversity. In similar biotopes of the Protected Area, Rana arvalis was present in unburnt areas, while Pelophylax lessonae was typical for water bodies. Some small ponds were almost the only continuously existed water bodies in this part of the study area. They remained from a former settlement there. In these ponds, Pelophylax lessonae was commonly found. A total disappearance of the amphibian species from this area has been promoted by the «burning out» of all ponds in 2010. However, these water bodies had already been completely restored by 2012, but amphibians were still absent there. During the 2013 field season, we noted both amphibian species had abundance values, which were comparable to those on the unburnt sites in the Kerzhensky Nature Reserve. Such a rather rapid penetration of Pelophylax lessonae and Rana arvalis into the areas affected by the crown wildfire is explained by the proximity $(2.5-3.0 \mathrm{~km})$ of small streams, and a high flood during the 2013 spring season (Lebedinskii \& Pestov, 2016).

\section{Birds}

During the study period, we observed 142 bird species from 40 families and 14 orders, including $78 \%$ of resident bird species in the Protected Area (Bakka et al., 2015). During the study period, the species abundance varied between 79 and 118 bird species (Noskova et al., 2018).

After the 2010 wildfire impact, we revealed the main tendencies and some regional patterns of the bird fauna dynamics in the Kerzhensky Nature Reserve. Due to the tree fallout observed after the wildfire influence, the patchy character of the study area increased in general. In the forests affected by the surface wildfires, the mosaic character of the forest promoted both a gradual increase in the species richness, biomass and abundance of the bird populations during the nesting period.

The crown wildfire resulted in the decrease in ornithological indicators (species richness, total abundance) during the first post-fire year. However, the intense overgrowing of these sites by Epilobium angustifolium L. encouraged bird nesting in the forest edges and in dry valleys during the second postfire year. It consequently doubled the abundance of bird species. During the summers, the highest species richness was observing more frequently on the fire-damaged sites (excluding the area of the former settlement) than on the unburnt sites.

We revealed the regional specifics of the changes in bird fauna in the fire-affected sites. During the nesting period, we distinguished some bird species recognised as indicators of the fire-affected sites. There were Sylvia communis Latham, 1787, Acrocephalus dumetorum Blyth, 1849 , A. palustris (Bechstein, 1798), Motacilla alba Linnaeus, 1758, and Lanius collurio Linnaeus, 1758. These bird species were more abundant or even dominant in the fire-affected sites, while they never were abundant in unburnt forests. For example, in burnt areas, we observed more frequently Motacilla alba and $\mathrm{La}$ nius collurio, than others species-indicators. However, after the 2010 wildfire impact, the same species has not been reported in the Oka State Nature Biosphere Reserve (Nikolaev, 2015).

Concerning birds confined to forest edges in the burnt sites of the Kerzhensky Nature Reserve, their abundance has increased only by the third post-fire year. This concerned mainly Anthus trivialis (Linnaeus, 1758), Muscicapa striata (Pallas, 1764), and Phylloscopus trochilus (Linnaeus, 1758). During the 2017 nesting period, these bird species prevailed everywhere with the exception of both unburnt and lightly burnt forest sites (28-54\% of total bird abun- 
dance). On the unburnt sites, the proportion of the forest-confined species increased during the last three study years. In 2015, it increased up to $66 \%$ of the total abundance value, in 2016 - up to $72 \%$, in 2017 - up to $77 \%$. During the post-nesting period, their proportion increased up to $40-72 \%$ over the five years (i.e. by 2017). In the burnt areas, this tendency was more common through the increase in abundance of the Paridae broods.

In all habitats, Fringilla coelebs Linnaeus, 1758 was an absolute dominant species based on the abundance values during the nesting period. Its abundance was up to $45 \%$ in unburnt sites and up to $34 \%$ in burnt areas (Table 2). Actually, this species had no co-dominants in the unburnt areas.

On the burnt sites and in the unburnt raised bogs, Anthus trivialis was a co-dominant of Fringilla coelebs (both species had up to $24 \%$ of total abundance). These two bird species dominated also on the burnt forest sites in the Oka State Nature Biosphere Reserve and the Balakhna lowland. In the latter case, Anthus trivialis dominated more frequently than Fringilla coelebs (Nikolaev, 2015; Shmeleva, 2017). In the burnt sites of the Kerzhensky Nature Reserve, Sylvia communis and (in some years) Phyl- loscopus trochilus (both species had on average 11$13 \%$ of the total abundance) were considered as codominants during the fourth and fifth years after the wildfire influence. In the fourth year after the 2010 wildfire (i.e. 2014), the Sylvia communis dominated also in the Oksky State Nature Biosphere Reserve, where this species shared this dominance status together with Erithacus rubecula (Linnaeus, 1758). The increased abundance of these species, together with Phylloscopus trochilus, can be caused by the development of Betula pendula Roth undergrowth on the fire-damaged sites (Nikolaev, 2015).

During the first three post-fire years in the Kerzhensky Nature Reserve, Fringilla coelebs dominated actually everywhere (up to $30 \%$ ) through the post-nesting period. Parus montanus Conrad von Baldenstein, 1827 (up to 25\%) and Parus major Linnaeus, 1758 (up to $38 \%$ ) dominated only in the unburnt raised bogs. During the study period, these three bird species were most frequent co-dominants. Since 2015, Parus montanus has been the most abundant bird species in most habitats (up to 37\%). Anthus trivialis (up to 28\%) and Fringilla coelebs (up to $30 \%$ ) were also two of the most abundant species, but less frequent.

Table 2. The most abundant nesting birds observed in the Kerzhensky State Nature Biosphere Reserve after the 2010 wildfire (\% of total bird abundance)

\begin{tabular}{|c|c|c|c|c|c|}
\hline \multirow{3}{*}{ Year } & \multicolumn{5}{|c|}{ Habitat types } \\
\hline & \multicolumn{3}{|c|}{ Birch-pine forests } & \multicolumn{2}{|c|}{ Raised bogs } \\
\hline & $\begin{array}{l}\text { severely burnt (after the } \\
\text { crown wildfire) }\end{array}$ & $\begin{array}{l}\text { lightly burnt (after the } \\
\text { surface wildfire) }\end{array}$ & unburnt & burnt & unburnt \\
\hline 2011 & $\begin{array}{c}\text { Fringilla coelebs (28), } \\
\text { Anthus trivialis (12), } \\
\text { Phylloscopus trochilus } \\
\text { (11) }\end{array}$ & $\begin{array}{l}\text { Fringilla coelebs }(34), \\
\text { Phylloscopus collybita } \\
\text { (10) }\end{array}$ & Fringilla coelebs (45) & $\begin{array}{c}\text { Fringilla coelebs (32), } \\
\text { Phylloscopus trochilus } \\
\text { (13), Anthus trivialis } \\
(10)\end{array}$ & $\begin{array}{c}\text { Fringilla coelebs (32), } \\
\text { Phylloscopus trochilus } \\
\text { (14), Anthus trivialis } \\
\text { (14) }\end{array}$ \\
\hline 2012 & $\begin{array}{c}\text { Fringilla coelebs }(24), \\
\text { Anthus trivialis }(24)\end{array}$ & $\begin{array}{c}\text { Fringilla coelebs }(31), \\
\text { Anthus trivialis }(17)\end{array}$ & $\begin{array}{l}\text { Fringilla coelebs }(28), \\
\text { Parus montanus }(12)\end{array}$ & $\begin{array}{c}\text { Fringilla coelebs }(20), \\
\text { Anthus trivialis }(11)\end{array}$ & $\begin{array}{c}\text { Fringilla coelebs (25), } \\
\text { Anthus trivialis (11) }\end{array}$ \\
\hline 2013 & $\begin{array}{l}\text { Anthus trivialis (20), } \\
\text { Fringilla coelebs (16) }\end{array}$ & $\begin{array}{c}\text { Fringilla coelebs }(24), \\
\text { Anthus trivialis }(14)\end{array}$ & Fringilla coelebs (34) & Fringilla coelebs (23) & $\begin{array}{c}\text { Fringilla coelebs (27), } \\
\text { Anthus trivialis }(18), \\
\text { Parus montanus (12) }\end{array}$ \\
\hline 2014 & $\begin{array}{l}\text { Fringilla coelebs (18), } \\
\text { Anthus trivialis }(14), \\
\text { Sylvia communis }(11)\end{array}$ & Fringilla coelebs (21) & Fringilla coelebs (29) & $\begin{array}{l}\text { Fringilla coelebs }(16), \\
\text { Sylvia communis }(12)\end{array}$ & $\begin{array}{c}\text { Fringilla coelebs (36), } \\
\text { Anthus trivialis (20) }\end{array}$ \\
\hline 2015 & $\begin{array}{l}\text { Fringilla coelebs }(18), \\
\text { Anthus trivialis }(14), \\
\text { Sylvia communis }(13)\end{array}$ & $\begin{array}{l}\text { Fringilla coelebs }(16), \\
\text { Anthus trivialis }(13), \\
\text { Parus montanus }(10)\end{array}$ & Fringilla coelebs (30) & $\begin{array}{l}\text { Fringilla coelebs }(18), \\
\text { Anthus trivialis }(14), \\
\text { Sylvia communis }(12)\end{array}$ & $\begin{array}{l}\text { Fringilla coelebs (24), } \\
\text { Anthus trivialis (19), } \\
\text { Parus montanus (12) }\end{array}$ \\
\hline 2016 & $\begin{array}{l}\text { Fringilla coelebs }(21) \\
\text { Anthus trivialis }(18)\end{array}$ & $\begin{array}{c}\text { Fringilla coelebs (25), } \\
\text { Anthus trivialis (13), } \\
\text { Phylloscopus trochilus } \\
\text { (11) }\end{array}$ & $\begin{array}{l}\text { Fringilla coelebs }(34), \\
\text { Parus montanus }(13)\end{array}$ & $\begin{array}{c}\text { Fringilla coelebs }(16), \\
\text { Anthus trivialis }(14)\end{array}$ & $\begin{array}{c}\text { Fringilla coelebs (32), } \\
\text { Anthus trivialis (18) }\end{array}$ \\
\hline 2017 & $\begin{array}{c}\text { Anthus trivialis (19), } \\
\text { Fringilla coelebs (17), } \\
\text { Phylloscopus trochilus } \\
\text { (17) }\end{array}$ & $\begin{array}{c}\text { Fringilla coelebs }(30), \\
\text { Anthus trivialis }(13)\end{array}$ & Fringilla coelebs (43) & $\begin{array}{c}\text { Anthus trivialis }(20), \\
\text { Fringilla coelebs (18), } \\
\text { Phylloscopus trochilus } \\
(12)\end{array}$ & $\begin{array}{l}\text { Anthus trivialis (19), } \\
\text { Fringilla coelebs (16) }\end{array}$ \\
\hline $\begin{array}{l}\text { Aver- } \\
\text { age }\end{array}$ & $\begin{array}{l}\text { Fringilla coelebs (19), } \\
\text { Anthus trivialis (18) }\end{array}$ & $\begin{array}{l}\text { Fringilla coelebs }(25), \\
\text { Anthus trivialis }(13)\end{array}$ & Fringilla coelebs (34) & $\begin{array}{l}\text { Fringilla coelebs (20), } \\
\text { Anthus trivialis (12) }\end{array}$ & $\begin{array}{l}\text { Fringilla coelebs }(27), \\
\text { Anthus trivialis }(17)\end{array}$ \\
\hline
\end{tabular}


The abundance and biomass of the nesting birds increased both on burnt and on unburnt sites during the first post-fire years with subsequent stabilisation (Noskova et al., 2014). During the last five post-fire years, we observed generally lower values of indicators among the avifauna in the unburnt bogs and in the unburnt birch-pine (Betula pendula-Pinus sylvestris) forests (Fig. 2).

The comparison of interannual post-fire dynamics in nesting abundance of the bird species has revealed some comparable changes in the avifauna of unburnt birch-pine forests, burnt raised bog, as well as both severely and lightly burnt birch-pine forests during seven post-fire years. For the first two habitats, an almost two-fold increase in abundance of the bird species was observed in the second year after the fires. We then noted an increase in the indicators in the third year in all four habitats. However, in the fourth year, the indicators of these bird species declined, while these hardly changed in total within the next three years.

Such co-ordinated changes in the abundance have been caused by both the weather conditions of a particular year, as well as by the vegetation successions on the burnt sites. For example, the avifauna structure in unburnt birch-pine forests could resemble one in burnt raised bog, where the birch undergrowth forms homogeneous dense thickets beginning from the first post-fire year. The severely and lightly burnt birch-pine forests alternate mosaically with each other. Therefore, interannual post-fire dynamics of the bird species abundance was similar within these habitats.

In the first post-fire year, the avifauna of the burnt areas of different types were similar for the forest sites and bogs, because these habitats have a mosaic structure (Fig. 3). Over the seven years, this similarity was increasing, especially between the avifauna in the burnt bogs and the severely burnt birch-pine forests. This was likely caused by simultaneous developing of birch undergrowth in these burnt sites (Noskova et al., 2018).

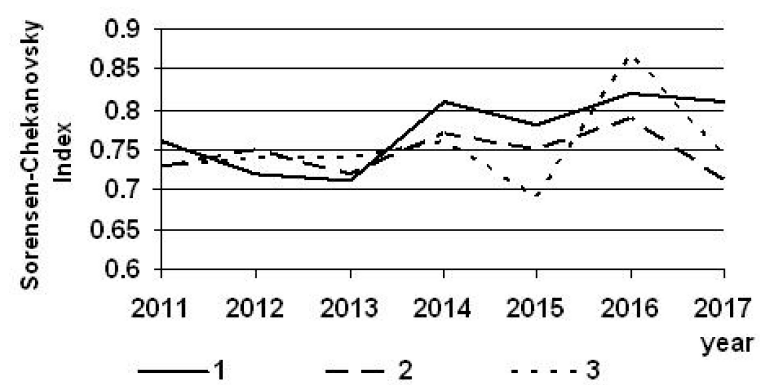

Fig. 3. Interannual post-fire dynamics similarity of nesting avifauna on the burnt sites in the Kerzhensky State Nature Biosphere Reserve after the 2010 wildfire. Designations of habitats: 1 - severely burnt (crown wildfire) birch-pine (Betula pendula - Pinus sylvestris) forests and burnt raised bogs, 2 - severely burnt (crown wildfire) and lightly burnt (surface wildfire) birch-pine forests, 3 - lightly burnt (surface wildfire) birch-pine forests and burnt raised bogs.
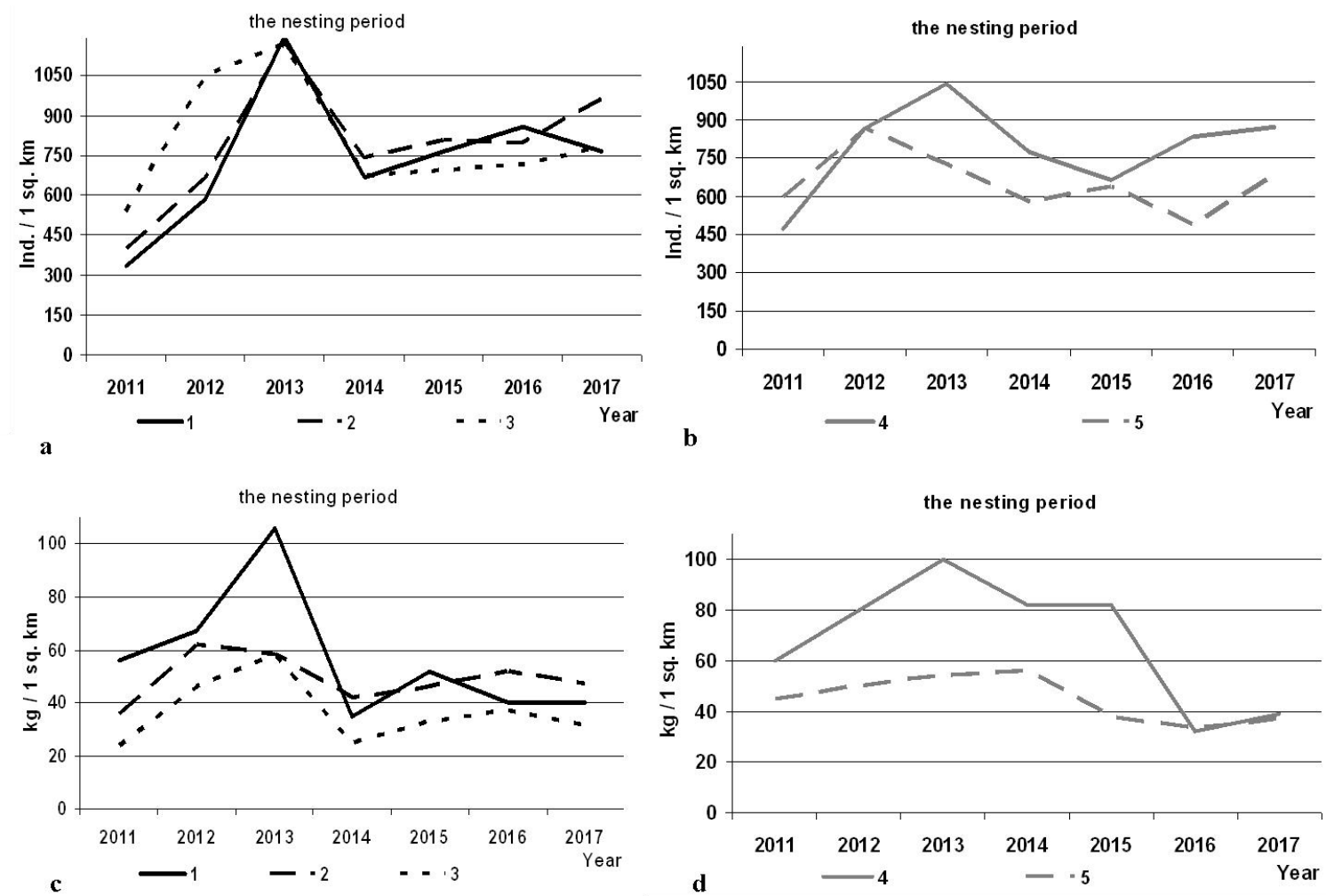

Fig. 2. Interannual post-fire dynamics of the cumulative abundance $(a, b)$ and biomass $(c, d)$ of the nesting bird species in different habitats in the Kerzhensky State Nature Biosphere Reserve. Designations of study sites: 1 - severely burnt (after the crown wildfire) birch-pine (Betula pendula - Pinus sylvestris) forests; 2 - lightly burnt (after the surface wildfire) birch-pine forests; 3 - unburnt birch-pine forests; 4 - burnt raised bogs; 5 - unburnt raised bogs. 


\section{Small mammals}

In the Kerzhensky Nature Reserve, the small mammal fauna was studied continuously during four years starting since the creation of this Protected Area in 1993. It provided an opportunity to compare the data on this vertebrate group before and after the 2010 wildfire. The summarised data on the species diversity and the species abundance of the small mammals in the Kerzhensky Nature Reserve is presented in Table 3 (Dmitriev et al., 2016).

In total, 20 small mammal species were recorded in the Kerzhensky Nature Reserve. The most abundant and widespread were Clethrionomys glareolus Schreber, 1780, Sorex araneus Linnaeus, 1758, Apodemus uralensis Pallas, 1811, and A. flavicollis Melchiorm, 1834 (Table 3).
The severe 2010 wildfire led to a considerable decrease in abundance of the small mammals. Before the wildfire impact, their relative abundance was $10.6 \%$ per 100 trap-days, while after the 2010 wildfire this value was $4.34 \%$ per 100 trap-days. Thus, the relative abundance decreased almost in three-fold. In 2011, the Shannon index of species diversity was found to be more than three-fold lower in comparison with its value before the 2010 wildfire ( 0.25 against 0.85 , respectively) (Table 4). It demonstrated an instability of the small mammal communities caused by the excessive 2010 wildfire. During two post-fire years, we noted some fluctuations of species diversity at a generally low level. In 2014, however, we observed an almost two-fold increase in species diversity; in 2015 the diversity reached the pre-fire level.

Table 3. The species diversity, absolute and relative (\% from 100 trap-days) abundance of small mammals in the Kerzhensky State Nature Biosphere Reserve before and after the 2010 wildfire

\begin{tabular}{|c|c|c|c|c|c|c|c|c|c|c|c|c|}
\hline \multirow[b]{4}{*}{ Species } & \multicolumn{12}{|c|}{ Abundance per year } \\
\hline & \multirow{2}{*}{\multicolumn{2}{|c|}{$\begin{array}{c}\text { before } 2010 \\
1993-1997\end{array}$}} & \multicolumn{10}{|c|}{ after the 2010 wildfire } \\
\hline & & & \multicolumn{2}{|c|}{2011} & \multicolumn{2}{|c|}{2012} & \multicolumn{2}{|c|}{2013} & \multicolumn{2}{|c|}{2014} & \multicolumn{2}{|c|}{2015} \\
\hline & 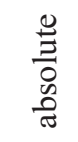 & 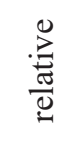 & $\begin{array}{l}\stackrel{0}{\Xi} \\
\frac{0}{0} \\
\text { है }\end{array}$ & 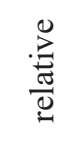 & $\begin{array}{l}\frac{0}{\Xi} \\
0 \\
0 \\
\text { है }\end{array}$ & 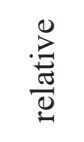 & 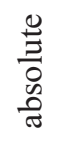 & 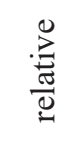 & 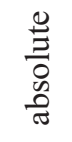 & 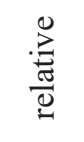 & $\begin{array}{l}\stackrel{0}{\Xi} \\
0 \\
0 \\
\text { 吕 }\end{array}$ & 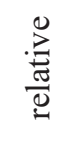 \\
\hline Sorex araneus Linnaeus, 1758 & 199 & 2.49 & - & - & 2 & 0.04 & 2 & 0.06 & 13 & 0.30 & 38 & 0.70 \\
\hline Sorex caecutiens Laxmann, 1788 & 18 & 0.23 & - & - & 2 & 0.04 & - & - & 2 & 0.04 & 7 & 0.10 \\
\hline Sorex minutus Linnaeus, 1766 & 25 & 0.31 & - & - & - & - & - & - & - & - & - & - \\
\hline Neomys fodiens Pennant, 1771 & 10 & 0.13 & - & - & - & - & - & - & - & - & - & - \\
\hline Cricetus cricetus Linnaeus, 1758 & 6 & 0.08 & - & - & - & - & - & - & - & - & - & - \\
\hline Clethrionomys glareolus Schreber, 1780 & 217 & 2.71 & 17 & 0.56 & 80 & 1.74 & 9 & 0.25 & 44 & 0.98 & 128 & 2.00 \\
\hline Microtus arvalis Pallas, 1779 & 12 & 0.15 & - & - & - & - & - & - & - & - & - & - \\
\hline Arvicola terrestris Linnaeus, 1758 & 9 & 0.11 & - & - & - & - & - & - & - & - & - & - \\
\hline Microtus agrestis Linnaeus, 1761 & 4 & 0.05 & - & - & 4 & 0.08 & 1 & 0.03 & 3 & 0.07 & 8 & 0.20 \\
\hline Microtus oeconomus Pallas, 1776 & 2 & 0.03 & - & - & 1 & 0.02 & - & - & 2 & 0.04 & 7 & 0.10 \\
\hline Apodemus uralensis Pallas, 1811 & 169 & 2.11 & - & - & 29 & 0.63 & 12 & 0.33 & 62 & 1.4 & 163 & 2.60 \\
\hline Apodemus agrarius Pallas, 1771 & 15 & 0.19 & - & - & 4 & 0.08 & 3 & 0.08 & 4 & 0.09 & 17 & 0.30 \\
\hline Apodemus flavicollis Melchiorm, 1834 & 110 & 1.38 & 114 & 3.77 & 70 & 1.52 & 41 & 1.12 & 36 & 0.80 & 87 & 1.40 \\
\hline Mus musculus Linnaeus, 1758 & 2 & 0.03 & - & - & - & - & - & - & - & - & - & - \\
\hline Micromys minutes Pallas, 1771 & 1 & 0.01 & - & - & - & - & - & - & - & - & - & \\
\hline Rattus norvegicus Berkenhout, 1769 & 1 & 0.01 & - & - & - & - & - & - & - & - & - & - \\
\hline Sicista betulina Pallas, 1778 & 1 & 0.01 & - & - & - & - & - & - & - & - & - & - \\
\hline Eliomys quercinus Linnaeus, 1766 & 43 & 0.54 & 9 & 0.30 & 3 & 0.06 & 4 & 0.12 & 9 & 0.20 & 2 & 0.04 \\
\hline Dryomys nitedula Pallas, 1778 & 2 & 0.03 & - & - & - & - & - & - & 1 & 0.02 & 1 & 0.02 \\
\hline Ondatra zibetica Linnaeus, 1766 & - & - & - & - & - & - & 1 & 0.03 & - & - & - & - \\
\hline Total & 846 & 10.6 & 140 & 4.6 & 195 & 4.2 & 74 & 2.03 & 176 & 3.7 & 458 & 7.2 \\
\hline
\end{tabular}

Table 4. The ecological indices for the small mammal communities in the Kerzhensky State Nature Biosphere Reserve before and after the 2010 wildfire

\begin{tabular}{|l|c|c|c|c|c|c|}
\hline \multirow{2}{*}{ Index } & \multicolumn{5}{c|}{ Year } \\
\cline { 2 - 8 } & \multicolumn{2}{|c|}{ before 2010 } & \multicolumn{5}{c|}{ after the 2010 wildfire } \\
\cline { 2 - 8 } & $1993-1997$ & 2011 & 2012 & 2013 & 2014 & 2015 \\
\hline Shannon index & 0.85 & 0.25 & 0.60 & 0.21 & 0.54 & 0.73 \\
\hline Pielou index & 0.66 & 0.52 & 0.67 & 0.50 & 0.63 & 0.69 \\
\hline Simpson-Margalef index & 2.67 & 0.40 & 1.42 & 0.36 & 1.53 & 1.88 \\
\hline Simpson index of domination & 0.19 & 0.67 & 0.30 & 0.44 & 0.32 & 0.25 \\
\hline
\end{tabular}


During the study years, the Pielou index fluctuated within a limited range. Nevertheless, its maximum value was observed before the 2010 wildfire influence. Only in 2015, it almost reached the level recorded before the wildfire impact. We also observed a similar situation for the Shannon index. However, its sharp decline in 2011, when only three small mammal species were recorded, was more striking. The minimal values of these indices were registered in 2011. It demonstrated the damage of the ecological structure of the small mammal communities caused by 2010 wildfire impact. Starting since 2014, we noted a tendency of the small mammal communities to exit from the phase of abundance depression. The 2010 wildfire had led to a remarkable domination of one species, Apodemus flavicollis (Simpson index of domination: 0.67) in 2011. Before the wildfire impact, Sorex araneus, Clethrionomys glareolus and Apodemus uralensis (Simpson's index of domination: 0.19) dominated. However, the Simpson index decreased in 2015. It suggests a gradual restoration of the small mammal communities in the Kerzhensky Nature Reserve by 2015 .

Using the one-dimensional dispersive analysis, we estimated quantitatively the influence force of the severe wildfire and the reliability of the wildfire impact on the small mammal communities. The wildfire influence force was 0.445 (p-level $<1)$. The confidence interval was ranging from 0.412 to 0.478 . The Fischer's criterion tabular was 3.40 . It had less actual value (13.66). According to these data, $\mathrm{F}_{\mathrm{ex}}>\mathrm{F}_{\mathrm{st}}$ with the $\mathrm{p}$-level $<0.01$. Thus, the wildfire influence on the small mammal abundance was not less than $41.2 \%$. And it was no more than $47.8 \%$ of the general influence of all sums of the factors taking into account the confidence intervals of the universe even at $1 \%$ significance value. Thus, we demonstrated that the severe wildfire statistically reliably affects the abundance and ecological structure of small mammal communities. The contribution of this factor was very high $(41-48 \%)$ in the total amount of all factors influencing on abundance. Thus, with a high degree of reliability, we confirmed that severe wildfire radically changed the living conditions of the small mammals, not only in the burnt areas, but also in the adjacent territories (Dmitriev et al., 2016).

\section{Conclusions}

On the basis of the above-mentioned results, we can draw the following conclusions.
The 2010 wildfire had a significant impact on the Tetrapoda fauna in the Kerzhensky Nature Reserve. At the same time, the specifics of this influence on the different animal groups were varying. The amphibians and small mammals were found generally to be the most vulnerable. Their vulnerability was caused by their dependence on water body availability, and on the high level of biotope humidity. On the other hand, their vulnerability has been explained by confinement to the area, as well as by their limited ability to migrate rapidly and far in order to escape the fire-caused damage. Birds were the least vulnerable to the wildfire effect, because these animals are capable to actively avoid wildfire influence. In addition, they were able to inhabit the burnt areas, and come back again, once the appropriate nesting conditions are restored or even improved, because of the succession specifics.

In the case of birds and small mammals, the wildfire caused species redistribution, multidirectional dynamics of the abundance indicators and replacement of the dominants on a study site. In the burnt areas, we identified bird species considered as indicators of wildfire impact. These species were more abundant in burnt sites in comparison with similar unburnt sites. But they could never or only occasionally dominate. Among these bird species-indicators were Sylvia communis, Acrocephalus dumetorum, A. palustris, Motacilla alba, and Lanius collurio. Among the small mammals, Apodemus flavicollis was considered as a speciesindicator. Among the amphibians and reptiles, no such species were revealed. Instead there was a proportional decline in abundance, followed by the subsequent proportional recovery in these two groups of Tetrapoda fauna.

The recovery rates of each species abundance in the concerning Tetrapoda groups were different. The herpetofauna recovered after three post-fire years, whereas the formation of the post-fire communities in birds and small mammals took 4-5 years. Therefore, generally the most intense changes have been observed within five years after the 2010 wildfire influence in Tetrapoda populations in the Kerzhensky Nature Reserve. Wildfires occur with a certain frequency in this area. Their recurrence is apparent, and allowed to develop both a tolerance of Tetrapoda animals to the wildfire impact and mechanisms of the rapid post-fire restoration of these animals. 


\section{Acknowledgements}

The authors express their gratitude to the staff of the Kerzhensky State Nature Biosphere Reserve for allowing them to carry out this study. We are also grateful to M.V. Pestov, O.N. Kalinina, A.N. Gnetneva, V.V. Malchenko, Yu.A. Sorokina, N.E. Kolesova, S.V. Bakka, L.N. Odrova, D.M. Krivonogov, and M.A. Trushkova for their help in collecting field material. We are indebted to S.V. Bakka for providing us with a schematic map of the Kerzhensky State Nature Biosphere Reserve and to the scientific department of the Kerzhensky State Nature Biosphere Reserve for providing us with a schematic map of the 2010 wildfire in this Protected Area.

\section{References}

Bakka S.V., Kiseleva N.Yu. 2009. Protected Areas of the Nizhny Novgorod Region. Annotated list. Nizhny Novgorod. 560 p. [In Russian]

Bakka S.V., Kiselyova N.Yu., Odrova L.N. 2015. Vertebrate animals of the Kerzhensky State Nature Reserve (annotated list). Proceedings of the Kerzhensky State Nature Reserve 7: 6-59. [In Russian]

Bond W.J., Keeley J.E. 2005. Fire as a global 'herbivore': the ecology and evolution of flammable ecosystems. Trends in Ecology and Evolution 20(7): 419-442. DOI: 10.1016/j.tree.2005.04.025

Bowman D.M., Balch J.K., Artaxo P., Bond W.J., Carlson J.M., Cochrane M.A., D’Antonio C.M., DeFries R.S., Doyle J.C., Harrison S.P., Johnston F.H., Keeley J.E., Krawchuk M.A., Kull C.A., Marston J.B., Moritz M.A., Prentice I.C., Roos C.I., Scott A.C., Swetnam T.W., van der Werf G.R., Pyne S.J. 2009. Fire in the Earth system. Science 324(5926): 481-484. DOI: 10.1126/science. 1163886

Buyvolov A.Yu., Bykova E.P., Gavrilenko V.S., Fungi A.V., Bazhenov Yu.And., Borodin A.P., Goroshko A.O., Kirilyuk V.E., Korsun O.V., Kreydlin M.L., Kuksin G.V., Ryabinina Z.N. 2012. Analysis of domestic and foreign experience of management of the fires in steppes and related ecosystems, in particular, Protected Areas. Moscow: Institute of the Global Climate and Ecology of RosHydromet and RAS. 170 p. [In Russian]

Dementiev G.N., Gladkov V.A. (Ed.). 1951-1954. Birds of the Soviet Union. Moscow: Sovetskaya Nauka. Vol. 1-6. 652 p., 480 p., 680 p., 640 p., 803 p., 792 p. [In Russian]

Dmitriev A.I., Krivonogov D.M., Trushkova M.A., Zamoreva Zh.A. 2016. The assessment of living conditions of the small mammal communities after the severe 2010 wildfire in the conditions of the protection regime. Proceedings of the Kerzhensky State Nature Reserve 8: 85-95. [In Russian]

Fisher J.T., Wilkinson L. 2005. The response of mammals to forest fire and timber harvest in the North American boreal forest. Mammal Review 35(1): 51-81. DOI: 10.1111/j.1365-2907.00053.x

Furyaev V.V. 1996. A role of the fires in the course of a forests formation. Novosibirsk: Nauka. 253 p. [In Russian]
Gongalsky K.B. 2014. Strong fires and soil fauna. Moscow: KMK Scientific Press Ltd. 169 p. [In Russian]

Granström A. 2001. Fire Management for Biodiversity in the European Boreal Forest. Scandinavian Journal of Forest Research 16(sup003): 62-69. DOI: 10.1080/028275801300090627

Herrando S., Brotons L., Llacuna S. 2005. Post-fire dynamics in Mediterranean shrublands: are bird communities structured by arthropod availability? Revista Catalana d'Ornitologia 21: 17-28.

Holliday N.J. 1984. Carabid beetles (Coleoptera: Carabidae) from a burned spruce forest (Picea spp.). Canadian Entomologist 116(7): 919-922. DOI: 10.4039/Ent116919-7

Holliday N.J. 1992. The carabid fauna (Coleoptera: Carabidae) during post-fire regeneration on boreal forest: properties and dynamics of species assemblages. Canadian Journal of Zoology 70(3): 440-452. DOI: 10.1139/ z92-067

Hossack B.R., Lowe W.H., Corn P.S. 2013. Rapid increases and time lagged declines in amphibian occupancy after wildfire. Conservation Biology 27(1): 219-228. DOI: 10.1111/j.1523-1739.2012.01921.x

Ibragimov A.K., Konkin S.F. 1983. Post-fire dynamics of the avifauna in the pine forests of Gorky Zavolzhye. In: Ecological-faunistic studies in a non-Chernozem zone of RSFSR. Saransk. P. 27-37. [In Russian]

Karaseva E.V., Telitsyna A.Yu. 1998. Methods of rodent studying in field conditions. Moscow: Nauka. 227 p. [In Russian]

Kuleshova L.V. 2009. The pulsing changes in distribution of Palearctic birds under the influence of severe fires. In: The ornithogeography of Palearctic: modern problems and prospects. Makhachkala. P. 147-153. [In Russian]

Lamotte M. 1975. The structure and function of a tropical savanna ecosystem. In: Tropical ecological systems: trends in terrestrial and aquatic research. Berlin: Springer Verl. P. 179-222. DOI: 10.1007/978-3642-88533-4

Lebedinskii A.A., Pestov M.V. 2014. Amphibians and reptiles of the Kerzhensky State Nature Reserve in connection with the pyrogenic succession after the 2010 severe wildfire. Proceedings of the Kerzhensky State Nature Reserve 6: 234-245. [In Russian]

Lebedinskii A.A., Pestov M.V. 2016. Ways of the post-fire herpetofauna restoration in the Kerzhensky State Nature Reserve. Proceedings of the Kerzhensky State Nature Reserve 8: 144-151. [In Russian]

Lebedinskii A.A., Pestov M.V. 2017. Features of post-wildfire recovery of forest herpetocomplexes as a consequence of physical and geographical peculiarities of the territory (on an example of the Kerzhensky Nature Reserve). Current Studies in Herpetology 17(1/2): 44-50. [In Russian] DOI: 10.18500/1814-6090-2017-17-1-2-44-50

Lussenhop J. 1976. Soil arthropod response to prairie burning. Ecology 57(1): 88-89. DOI: 10.2307/1936400 
Mannapova E.I., Pestov M.V. 2002. Herpetofauna of the Kerzhensky State Nature Reserve. Proceedings of the Kerzhensky State Nature Reserve 2: 71-77. [In Russian]

Mannapova E.I., Pestov M.V., Lebedinskii A.A. 1999. Amphibians and reptiles of the Kerzhensky State Nature Reserve. In: Second Conference of the Herpetologists of the Volga region. Togliatti. P. 37-38. [In Russian]

Margalef R. 1958. Information theory in ecology. International Journal of General Systems 3: 36-71.

Middendorf A.F. 1869. A travel on the North and the East of Siberia. Siberian fauna. Saint-Petersburg. 310 p. [In Russian]

Nikolaev N.N. 2015. Dynamics of the bird abundance in forest communities of the Oka State Nature Reserve affected by the 2010 wildfire. Proceedings of the Oka State Nature Reserve 33: 57-67. [In Russian]

Noskova O.S., Ruleva Yu.A., Kolesova N.E., Baranov S.A. 2017. Six-year dynamics of the nesting bird populations of the wetlands of the Kerzhensky Nature Reserve after the 2010 severe wildfires. In: West Siberian peat bogs and a cycle of carbon: the past and the present. Tomsk: Tomsk State University. P. 42-45. [In Russian]

Noskova O.S., Ruleva Yu.A., Kolesova N.E., Krupko M.S., Baranov S.A. 2014. Interannual and seasonal dynamics of the bird populations of the State Reserve "Kerzhensky» after the 2010 summer wildfire. Proceedings of the Kerzhensky State Nature Reserve 6: 245-254. [In Russian]

Noskova O.S., Sorokina Yu.A., Kolesova N.E., Bakka S.V., Odrova L.N., Baranov S.A. 2018. Changes of the summer bird population of Kerzhenets Nature Reserve within seven years after the strong fires of 2010. Ecosystems: Ecology and Dynamics 2(3): 29-36. [In Russian] DOI: 10.24411/2542-2006-2017-10014

Novikov G.A. 1949. The field studies of the terrestrial vertebrate ecology. Leningrad: Sovetskaya Nauka. 602 p. [In Russian]

Odum Yu. 1986. Ecology. Moscow: Mir. Vol. 1. 328 p. [In Russian]
Pausas J.G., Keeley J.E. 2009. A Burning Story: The Role of Fire in the History of Life. BioScience 59(7): 593-601. DOI:10.1525/bio.2009.59.7.10

Perera A., Buse L. 2014. Ecology of Wildfire Residuals in Boreal Forests. Wiley-Blackwell. 272 p.

Pielou E.C. 1966. The measurement of diversity in different types of biological collections. Journal of Theoretical Biology 13: 131-144. DOI: 10.1016/00225193(66)90013-0

Puzanov I.I., Kozlov V.I., Kiparisov G.I. 2005. Vertebrate animals of the Nizhny Novgorod region. Nizhny Novgorod. 544 p. [In Russian]

Ravkin Yu.S. 1967. About the count method of birds in the forest landscapes. Nature of the Focal Encephalitis in the Altai. Novosibirsk. P. 66-75. [In Russian]

Sannikov S.N. 1982. Forest fires as a factor of transformation of structure, regeneration, and evolution of biogeocenoses. Soviet Journal of Ecology 12(6): 328-337.

Shmeleva G.P. 2017. Fire impact on bird populations of the outwash plain (Balakhna lowland). In: Dynamics of the birds abundance in terrestrial landscapes. The 30 years of the programs of the wintering birds monitoring in Russia and adjacent regions. Moscow: KMK Scientific Press Ltd. P. 277-282. [In Russian]

Simpson E.H. 1949. Measurement of diversity. Nature 163: 688. DOI: 10.1038/163688a0

Ushakov V.A., Ibragimov A.K., Ushakov A.V. 1991. The dynamic of the avifauna of the pine forests in connection with the fires. In: Materials of X All-Union Ornithological Conference. Minsk. Vol. 2(2). P. 262-263. [In Russian]

Wikars L.O. 1997. Effects of forest fire and the ecology of fire-adapted insects. PhD Thesis. Uppsala: Sweden University of Uppsala. 35 p.

Zozaya E.L., Brotons L., Herrando S., Pons P., Rost J., Clavero M. 2010. Monitoring spatial and temporal dynamics of bird communities in Mediterranean landscapes affected by large wildfires. Ardeola 57: 33-50.

Zwolak R. 2009. A meta-analysis of the effects of wildfire, clearcutting, and partial harvest on the abundance of North American small mammals. Forest Ecology and Management 258(5): 539-545. DOI: $10.1016 /$ j.foreco.2009.05.033 
ПОСЛЕПОЖАРНОЕ ВОССТАНОВЛЕНИЕ НАЗЕМНЫХ ПОЗВОНОЧНЫХ В КЕРЖЕНСКОМ ГОСУДАРСТВЕННОМ ПРИРОДНОМ БИОСФЕРНОМ ЗАПОВЕДНИКЕ (СРЕДНЕЕ ПОВОЛЖЬЕ, РОССИЯ)

\author{
А. А. Лебединский ${ }^{1}$, О. С. Носкова ${ }^{1}$, А. И. Дмитриев ${ }^{2}$ \\ ${ }^{1}$ Нижегородский государственный университет имени Н.И. Лобачевского, Россия \\ e-mail:leb-nn@yandex.ru,noskova.o.s@gmail.com \\ ${ }^{2}$ Нижегородский государственный педагогический университет имени К. Минина, Россия \\ e-mail:dmitriev-50@mail.ru
}

\begin{abstract}
Летом 2010 г. около половины территории государственного природного заповедника «Керженский» (общая площадь 467.9 км²) пострадало от лесных пожаров. На протяжении следующих семи лет здесь вели мониторинг состояния популяций наземных позвоночных. Всего было отмечено шесть видов амфибий, шесть видов рептилий, 142 вида птиц и 20 видов мелких млекопитающих. Специфика воздействия пожаров на разные виды позвоночных отличается. В первый год после пожаров население птиц местообитаний, нарушенных разными типами пожаров, согласно индексу Сьеренсена-Чекановского, было сходным. Это сходство со временем росло. В то же время, если число видов изменялось часто в разных направлениях, как например, в нарушенных и ненарушенных местообитаниях в первые годы исследований, суммарное обилие населения птиц росло, хотя позднее этот показатель немного снизился и стабилизировался. Население птиц ненарушенных пожарами местообитаний отличалось более низкими показателями последние пять лет. Были отмечены виды-индикаторы гарей (такие как Sylvia communis). Это виды, которые стали многочисленны в нарушенных пожарами лесах, но очень редко доминирующие и малочисленные на ненарушенной территории. Fringilla coelebs по обилию доминировал во всех местообитаниях. Напротив, обилие и экологические показатели сообществ мелких млекопитающих снизились (в 2-3 раза) после пожаров, сменились доминанты - с Clethrionomys glareolus на Apodemus flavicollis. Дисперсионный анализ показал, что пожары с высокой долей вероятности $(0.445 ;$ p-level $<1)$ влияют на сообщества мелких млекопитающих. В отношении амфибий и рептилий выявлено только снижение численности видов (и следующее за этим восстановление показателей), без изменения структуры населения. Наиболее интенсивные постпирогенные изменения в популяциях наземных позвоночных (Tetrapoda) произошли в течение первых пяти лет после пожаров. Население амфибий и рептилий восстановилось через 3 года, сообщества птиц и мелких млекопитающих - через 4-5 лет.
\end{abstract}

Ключевые слова: амфибии, верховой пожар, мелкие млекопитающие, низовой пожар, птицы, рептилии 